DOI: https://doi.org/10.32839/2304-5809/2021-4-92-66

удК 331.2

Машевська А.A.

Вінницький національний аграрний університет

\title{
ЕКОНОМІЧНА СУТНІСТЬ ТА ПІДХОДИ ДО ВИЗНАЧЕННЯ «ЗАРОБІТНА ПЛАТА»
}

Анотація. У статті розглянуто економічну сутність та підходи до визначення поняття «заробітна плата», проаналізовано фонкції зарплати, а також досліджено значення заробітної плати різними науковцями та вченими. Найбільша увага, при дослідженні, питань щодо економічної сутності заробітної плати, приділяеться вивченню основних чинників, що впливають на їі розмір та вирішенню питань щодо оптимального рівня зарплати. При написанні статті визначено основні функції зарплати, які пов'язані між собою, тому що, лише за їхньої сукупної наявності досягається ефективна організація заробітної плати. В статті зазначено також, що розмір зарплати, на рівні держави, залежить від таких макро-, мікро- показників як розподіл ВВП, обсяг виготовленої продукції, податки та надані субсидії.

Ключові слова: заробітна плата, оплата праці, фрунції заробітної плати, трудові відносини, роботодавець, грошова винагорода.

Mashevska Anzhelika

Vinnitsa National Agrarian University

\section{ECONOMIC SUMMARY AND APPROACH TO SALARY DEFINITION}

Summary. The article discusses the economic nature and approaches to the definition of "wages», analyzes the functions of wages, and explores the approach to determining the nature of wages by various scientists. Nevertheless, at the same time, the issue of wages in Ukraine remains unresolved. In the study, the questions of the economic nature of wages are given the greatest attention to the study of the main factors affecting its size and the solution of problems of the optimal level of wages. When writing an article, the main functions of wages are determined, which are interconnected, because only with their combined availability is effective organization of wages achieved. The article also noted that the size of the salary at the state level depends on such macro- and micro-indicators as the distribution of GDP, the volume of output, taxes and the provision of subsidies. Wages have always been the main tool of material and motivational mechanism of labor activity of employees. To date, there is no proposed comprehensive approach to defining the essence of wages as a holistic model that is formed at different levels of the economy, there are no scientifically sound principles of public policy on wages. Therefore, the question of determining the nature of wages remains relevant and is being studied by various scholars. In their works, domestic and foreign economists study in detail the most important problems of wages, where most attention is paid to the study of the main reasons that affect its size. In economic periodicals, there is no single approach to the definition and essence of wages, to solve problems that arise in the labor market for state regulation of wages, and this, in turn, leads to further study of this issue. The organization of remuneration is a system of organizational and legal means aimed at establishing the content and procedure for introducing the system of remuneration, tariff system, labor rationing, piece rates, bonuses, other incentive, compensation and guarantee payments, setting remuneration in case of deviation from tariff conditions, forms and terms of payment of wages, the procedure for calculating average earnings, indexation of wages in connection with changes in the consumer price index, wage compensation in connection with the violation of the terms of its payment. So, the organization of the salary system at an industrial enterprise requires carefully thoughtout steps in the preparation and implementation of a flexible model taking into account performance criteria that increase the interest of employees in individual indicators and in the results of the work of the business subjective. The construction of wage systems is a rather difficult task for any production, since it is difficult to take into account all the individual nuances in the organization and structure for each particular enterprise. At the same time, the further development of standards and the development of procedures based on the best practice of introducing systems of labor organization at work will help to balance and match between individual features and universal methods in organizing production processes. Having investigated the functions of remuneration, we propose to highlight the main such as: reproductive, stimulating, regulatory and social, each of which has its own mechanism of implementation, as other functions only duplicate the basic, despite the variations in names and approaches.

Keywords: salary, wages, wage functions, labor relations, employer, money reward.

Постановка проблеми. Заробітна плата завжди виступала основним інструментом матеріального та мотиваційного механізму трудової активності працівників.

На сьогодні немає запропонованого единого комплексного підходу до визначення сутності заробітної плати як цілісної моделі, що формуеться на різних рівнях економіки, відсутні науково обтрунтовані засади державної політики щодо оплати праці. I тому питання визначення сутності заробітної плати залишається актуальним і досліджуеться різними науковцями.
Аналіз останніх досліджень і публікацій. Аналіз та проблематику економічної сутності заробітної плати в Україні досліджують багато науковців, а саме Глухова С.В. [1], Сьомченко В.В. [2], Маркевич А.Є. [3], Мочерний С.В. [9], Грішнова О.А. [14], Буряк П.Ю. [16], Швиданенко Г.О. [19] та багато інших.

У своїх роботах вітчизняні та закордонні економісти детально досліджують найважливіші проблеми заробітної плати, де найбільше звертаеться увага на вивчення основних причини, що впливають на її розмір. 
Виділення не вирішених раніше частин загальної проблеми. Детальне вивчення наукової літератури і нормативно-правових актів свідчить про те, що основна частина ключових понять щодо визначення теоретичної сутності заробітної плати розроблена досить грунтовно. Але, одночасно, можна відмітити, що немае единого підходу до визначення понять заробітна плата, до вирішення проблем, що виникають на ринку праці щодо державного регулювання заробітної плати, а це, в свою чергу, призводить до подальшого вивчення даного питання.

Мета статті. Основною метою написання наукової статті є дослідження та вивчення економічної сутності та підходів до визначення поняття «заробітна плата».

Виклад основного матеріалу. На сьогодні, в системі трудових відносин, зарплата займає одне $з$ основних місць. Всі підприемства мають можливість обирати в якому напрямку використовувати свої трудові ресурси, визначати форми і розміри заробітної плати для працівників. В свою чергу, працівники, мають можливість вибирати підприемство яке пропонуе гідні умови праці та її оплати.

Фонд заробітної плати підприемства е істотним елементом розподільних відносин, важливим джерелом фінансових ресурсів, як і життедіяльність та соціальні потреби працівників підприемства. Ефективність функщіонування й соціальний розвиток підприемства забезпечуеться передусім формуванням належних індивідуальних і колективних матеріальних стимулів, провідною формою реалізації яких є науково обгрунтована система організації оплати праці різних категорій персоналу [1].

Організація оплати праці являе собою систему організаційно-правових засобів, спрямованих на встановлення змісту і порядку введення системи оплати праці, тарифної системи, нормування праці, відрядних розцінок, преміювання, інших заохочувальних, компенсаційних і гарантійних виплат, встановлення норм оплати праці при відхиленні від тарифних умов, форм і строків виплати заробітної плати, порядку обчислення середнього заробітку, індексації зарплати у зв'язку зі зміною індексу споживчих цін, компенсації зарплати у зв'язку з порушенням термінів її виплати. Організація оплати праці грунтуеться на наукових принципах, які враховують політику держави в забезпеченні мінімального рівня заробітної плати, рівень розвитку національної економіки та домінуючі форми власності й господарювання [8, с. 30].

Якщо зважити на політику держави, то можна зазначити, що організащія обліку оплати праці побудована на принципах науковості. А саме ці принципи покликані збільшити рівень підняття та розвитку української економіки.

В науковій літературі існуе не одне визначення економічної сутності заробітної плати, це пояснюеться тим, що скільки науковців стільки ж наукових поглядів.

Питання організації заробітної плати і формування ії рівня становлять основу соціальнотрудових відносин у суспільстві, бо включають нагальні інтереси всіх учасників трудового процесу. Будь-які зміни, що стосуються оплати праці, прямо чи опосередковано впливають на доходи всіх членів суспільства, а також на найважливіші макроекономічні показники. Тому в жодній країні світу питання регулювання оплати праці не залишені лише на розсуд ринкових сил, хоча методи, сфера, масштаби державного втручання в ці процеси в кожній країні різні [21].

Сутність поняття «заробітна плата» розкривають і досліджують не тільки науковці та вчені у своїх працях, де кожен з них дає свое визначення щодо зарплати, але й у нормативних документах таких як Закон України «Про оплату пращі», відповідно до якого, заробітна плата - це винагорода, обчислена в грошовому вираженні, яку за трудовим договором роботодавець виплачуе працівникові за виконану ним роботу [4].

У своїх наукових дослідженнях А. Сміт та Д. Piкардо визначили власне бачення поняття «заробітна плата». наприклад, А. Сміт зазначив, що «заробітна плата охоплюе вартість життевих засобів людини, щоб вона могла «працювати», а от Д. Рікардо вважав, що «заробітна плата є грошовим виразом «мінімуму засобів існування» [5, с. 245].

На думку В. Лукашевич, поняття «оплата праці» та «заробітна плата» - рівноцінні, хоча між ними і е певна відмінність: видатки на заробітну плату здійснюють із фонду заробітної плати, а інші заохочувальні виплати проводять коштом підприемства або «коштів спеціального призначення та цільових надходжень» [6, с. 248].

Також своє визначення поняття заробітна плата дає Маркевич А.Є. Він зазначае, що сутність заробітної плати розкриваеться у функціях, які вона повинна виконувати в процесі суспільного відтворення. У сучасній науковій літературі зустрічається достатня кількість тлумачень функцій оплати праці, при чому зміст однієї й тіеї ж функції у різних дослідників трактуеться по-різному.

В свою чергу Чанишева Г. та Болотіна Н. зазначали, що термін «оплата праці» ширший, i його цільове призначення спрямоване на організацію оплати праці, регламентацію їі окремих елементів та всієї системи правових засобів у цій cфері, тоді як поняття «заробітна плата» спрямоване на право окремого працівника отримувати грошову винагороду [7, с. 564].

Як уже зазначалось, сутність заробітної плати розкриваеться у її функціях. Слід також звернути увагу на те, що сьогодні у сучасній науковій літературі ми можемо зустріти не одне тлумачення функцій оплати праці та при чому зміст однієї й тієї ж фрункції у різних дослідників трактуеться по-різному.

Так, Мочерний С.В. у своїх працях серед основних функцій заробітної плати виділяе три: відтворювальну, стимулюючу та розподільчу [9, с. 398].

Гадзевич О.І. основною визначае стимулюючу, мотиваційну функцію трудових доходів працівників, але при цьому розглядае також такі функції заробітної плати, як відтворювальна та соціальна $[10$, с. 12$]$.

О.А. Грішнова розглядає шість функцій заробітної плати: стимулюючу, відтворювальну, соціальну, регулюючу, оптимізаційну та функцію формування платоспроможного попиту населення [16, с. 283].

Сліньков B.M. також розглядае шість функцій заробітної плати, але замість оптимізаційної, виділяе вимірювально-розподільчу [17, с. 298]. 
Ми знаємо, що в умовах ринкової економіки постають досить жорсткі умови та вимоги до організації оплати праці.

3 одного боку, підприємства повністю незалежні в організації праці та заробітної плати, визначенні розміру фонду заробітної плати, встановленні тарифних ставок і посадових окладів, преміюванні працівників.

3 іншого боку, підприемствам потрібно вишукувати резерви зниження затрат на заробітну плату і забезпечення якості продукції, для забезпечення конкурентоспроможності на ринку. I це все відбувається під наглядом державних органів, які встановлюють мінімальні розміри та тарифрні ставки [3].

Таким чином величину фронду заробітної платні трудового колективу, кожного робітника необхідно поставити у пряму залежність від досягнутих кінцевих результатів.

Планування заробітної платні повинно забезпечити ріст обсягу продукції, що виробляеться (послуг, робіт), підвищення ефективності виробництва та його конкурентоспроможності, підвищення матеріального стану трудящих. Планування фонду заробітної платні включає розрахунок суми фонду і середньої заробітної платні, як усіх робітників підприемства, так і за категоріями працівників [1, с. 698].

Слід виділити наступні види виплат, які визначаються згідно з чинним законодавством:

Основна зарплата - це винагорода за виконану роботу, згідно 3 встановленими нормами пращі. Вона встановлюється у вигляді тарифних ставок (окладів) і відрядних розцінок для робітників та посадових окладів для службовців

- додаткова 3/п - це винагорода за працю понад установлені норми, за трудові успіхи та винахідливість і за особливі умови праці. Вона включає доплати, надбавки, гарантійні i компенсаційні виплати, передбачені чинним законодавством; премії, пов'язані з виконанням виробничих завдань і функцій.

- інші компенсаційні та заохочувальні виплати - це виплати у формі винагород за підсумками роботи за рік, премії за спеціальними системами та положеннями, компенсаційні та інші грошові й матеріальні виплати, які не передбачено актами діючого законодавства, або які проводяться понад встановлені такими актами норми [1, с. 698].

Вважаємо, що в даному дослідженні слід визначитися з розумінням заробітної плати. Але для џого нам необхідно заробітну плату розглядати з декількох позицій, а саме, як зазначив Сьомченков В.В., - з позиції роботодавця - це коли заробітна плата $є$ головним чинником забезпечення матеріальної зацікавленості працівників і досягненні високих результатів своєї праці, та 3 позиціі найманого працівника - ми можемо розглядати заробітну плату, як основну частину його трудового доходу, який він отримуе в результаті реалізації здатності до пращі [2, с. 125].

Також, заробітна плата може бути визначена: як елемент ринку праці (іï рівень впливає на попит та пропозищію робочої сили); як «грошове вираження вартості та ціни товару «робоча сила» і частково результативності її фрункціонування» [5, с. 324]; як економічну категорію, що відображае стосунки роботодавця і найманого працівника [5, с. 185].
Аналізуючи вище викладене пропонуємо наступне визначення заробітної плати:

- заробітна плата - це ціна, якою оцінюеться праця робітника, яка повинна бути виражена тільки в грошовому еквіваленті, і стимулювати до високих результатів, а також виступає одним з елементів витрат виробництва.

В своїх наукових працях Швиданенко Г.О. зазначає - «оплата праці» - це будь який заробіток, обчислений, як правило, у грошовому виражені, який за трудовим договором власник або уповноважений ним орган виплачує працівникові за виконану роботу або надані послуги [18, с. 201].

В науковій економічній літературі можна зустріти різні підходи до визначення заробітної плати, коли автори поєднують різні тлумачення сутності оплати праці. В свою чергу, Воронін О. вважає, що «вартість робочої сили (витрати на їі відтворення) - це, насамперед, абстрактна, теоретична категорія.

Взаємовідношення між роботодавцем і найманим працівником на ринку праці мають схожість 3 орендними відносинами. Оскільки, на думку О. Вороніна, роботодавця цікавить не стільки повна вартість майна (робочої сили), скільки величина плати за їі використання (оплата праці) упродовж терміну оренди, оскільки орендодавець (найманий працівник) залишається власником своєї робочої сили» [19, с. 29].

В умовах ринкових відносин все вирішується в результаті взаємодії попиту на працю відповідної кваліфрікації з боку роботодавців і її пропозицією з боку найманих працівників, оскільки в результаті цієї взаємодії формується ринкова ціна використання найманої праці. Одночасно держава регулюе ринок праці [20, с. 133].

Тому, на наш погляд, є досить суттевим те, що заробітна плата виступає не тільки економічною категорією, а й соціально-економічною - i тому поєднує як інтереси робітників, роботодавців та держави так і є надзвичайно важливим показником рівня життя.

Звертаємо увагу на те, що підприемства самі можуть встановлювати правила розрахунку оплати праці своїх працівників 3 дотриманням діючого трудового законодавства. Однак, ніхто тут не винайде щось нове, так як все відтворюе уже існуючі форми і системи оплати праці [23].

До основних вимірників затрат на оплату праці можемо віднести кількість виготовленої продукщії або ж наданих послуг, виконаних робіт відповідної якості. В такому випадку ми можемо використовувати такі форми оплати праці, як погодинна та відрядна.

Усім звична оплата праці на основі окладу $є$ не чим іншим, як різновидом почасової оплати, так як нарахування по окладу залежить від кількості відпрацьованих днів (годин) за місяць. Така організація оплати праці називаються ще тарифна система, так як для ㄲï забезпечення в ідеальній ситуації необхідно розробити тарифні ставки, схеми посадових окладів, тарифонокваліфрікаційні характеристики тощо. Такий підхід є основним згідно ст. 96 КЗпП [23].

Як видно 3 таблиці 1, ми можемо зазначити, що системи оплати праці поділено на прості та складні. Складні варіанти, в свою, чергу, потребують більш глибокого продумування 
Форми та системи оплати праці та їх основна ідея

Таблиця 1

\begin{tabular}{|c|c|c|}
\hline \multicolumn{3}{|c|}{ Форми та системи оплати праці та їх основна ідея } \\
\hline \multirow{2}{*}{ Форми } & Почасова & Відрядна \\
\hline & Фактично відпрацьований час & Фактично вироблена кількість продукту \\
\hline \multirow{4}{*}{ Прості системи } & Проста почасова & Пряла відрядна \\
\hline & $\begin{array}{l}\text { Оклад (або погодинна, денна ставка) } \\
\text { і відпрацьований час }\end{array}$ & Є розцінка на кожну одиницю продукту \\
\hline & Почасова-преміальна & Преміально відрядна \\
\hline & $\begin{array}{l}\text { Оклад (або погодинна, денна ставка) } \\
\text { і відпрацьований час + премія }\end{array}$ & $\begin{array}{l}\text { За кількість + премія за виконання (перевиконання) } \\
\text { плану }\end{array}$ \\
\hline & \multirow{6}{*}{ Складні системи } & Відрядно-прогресивна \\
\hline & & Розцінки збільшуються по мірі виконання плану \\
\hline & & Непряма відрядна \\
\hline & & $\begin{array}{l}\text { Оплата працівника (зазвичай допоміжного) залежить } \\
\text { від результату роботи основних працівників }\end{array}$ \\
\hline & & Акордна \\
\hline & & $\begin{array}{l}\text { Оплата не за одиницю продукту, а за певний етап, } \\
\text { комплекс робіт }\end{array}$ \\
\hline
\end{tabular}

Джерело: [20]

та економічного обгрунтування, ретельної роботи нормувальника. Доцільність ії застосування можлива тільки у випадку, коли необхідно продумати мотиваційні чинники для працівників, а також, можливо, виправити певні перекоси у виробництві (перевиробництво, збільшення кількості браку, значний виробіток, але відсутність завершеності загального комплексу робіт).

В цілому всі ці системи може замінити прості варіанти з використанням премій. До розробки системи преміювання також можна підійти вдумливо й забезпечити досягнення тих же цілей, що й по складним системам.

Отже, при виборі форми та системи оплати пращі для кожного окремого працівника, слід обов'язково звертати увагу на умови та специфріку його роботи.

Звичайно, що кожна з існуючих фрорм має певні свої модифікації, підвиди, які мають забезпечити відповідність виробничій ситуації, особливостям мотивації працівників певного підприемства, бажання власника тощо. Основні ідеї існуючих систем оплати представлено в таблиці нижче [23].

Загальними умовами застосування тіеї чи іншої форми заробітної плати $є$ рівень технічного оснащення виробництва, характер технологічного процесу та організації виробництва і праці, ступінь використання виробничих потужностей і устаткування, стан нормування пращі тощо [20, с. 120].

Погодинна форма оплати пращі буде застосовуватись за годинними тарифрами, але за умови відпрацьованого робочого часу згідно кваліфікації та розряду працюючого. Також дана форма оплати пращі буде застосовуватись тоді, коли не доречно нормувати роботи або ж ці роботи не можуть підлягати нормуванню, тому що досить часто може змінюватись послідовність виробничих операцій.

Зазвичай погодинна оплата праці будується на основі тарифоної системи, яка включає в себе такі елементи, як:

- тарифбна сітка - таблиця з кваліфікаційними розрядами працівників, по ній визначається тарифнний розряд;

- тариббна ставка - норма оплати праці, тарифнна ставка першого розряду - норма оплати праці за найменш кваліфіковану працю;
- може визначатися як за лісяиь (посадовий оклад), так і за годину чи день, тиждень;

- схела посадових окладів - перелік посадових окладів та коедіцієнт по кожному з них, на основі коефіцієнту визначається оклад (тарифнна ставка) для конкретної посади;

- тарифбно-кваліфбкаиійний довідник - документ, що описує вимоги до посад, вміння та кваліфрікації працівника;

- штатний розпис - відображаються набір посад по підприемству та встановлені по ним посадові оклади, що визначені на основі схеми посадових окладів і тарифної ставки [ 22].

Для прикладу можемо навести таку ситуащію i проаналізувати яким чином на підприемствах може бути використана ця система оплати праці. Отже, на підприемстві для працівника бухгалтерії встановили перший тарифний розряд, а розмір заробітної плати складає 6000 грн. Також, для даної посади тарифний коефіцієнт встановлено 2,6. У тарифоно-кваліфікаційному довіднику прописані вимоги до посади: досвід роботи 3 роки, вища освіта тощо. Виходить, що посадовий оклад бухгалтера тоді буде складати: $6000 \times 2,6=15600$ грн.

Звертаємо увагу на те що, деякі підприємства, а особливо малі, взагалі можуть не мати схем посадових окладів та тарифрно-кваліфрікаційних довідників. Оклад визначається індивідуально або при складанні штатного розпису. Але для чіткого фрункціонування погодинної форми оплати праці на підприемстві має бути правильно організований облік робочого часу, тобто повинен вестися табель обліку робочого часу.

Для встановлення відрядної форми оплати праці необхідно:

- визначити спочатку місячні нормативи виробітку. Іншими словами провести нормування праці;

- визначити тарифні ставки по розрядах робіт (оплата проводиться саме по розряду робіт, а не розряду працівника; якщо між ними відхилення, то ще й треба платити між розрядну різницю згідно ст. 104 КЗПП);

- розрахувати відрядні розцінки (= тарифрна ставка/норма за місяць), ст. 90 КЗПП; 
- розробити та ввести внутрішні документи для обліку виробітку (саме на основі них буде нараховуватися зарплата, а не табелю обліку робочого часу, як це у почасової форми оплати праці) [22].

Для обліку виробітку застосовують такі документи:

- відомість обліку виробітку - загальний документ для обліку виробітку;

- маршрутний лист - для серійного виробництва;

- наряд на виробіток - для дрібносерійного виробництва;

- рапорт на виробіток - для потоково-масового виробництва

Також слід згадати про систему преміювання. Отже, якщо до системи окладів ще додаеться система преміювання, то проста погодинна система оплати праці перетворюються на погодинно-преміальну. Тут мається на увазі саме створена система преміювання, що підкріплюеться певним внутрішнім нормативним документом, наприклад, Положенням про преміювання [22].

Порівнюючи відрядну та погодинну фоорми оплати ми можемо побачити що, відрядна є більш складнішою.

Застосовувати на підприемстві відрядну систему оплати праці було б доцільно в таких випадках коли $е$ можливість точного обліку обсягів виконуваних робіт, або ж е значні замовлення на виготовлювану продукцію, а чисельність робітників обмежена. У випадку коли ж погіршуеться якість продукщії, порушуються технологічні режими, погіршуеться обслуговування устаткування, порушуються вимоги техніки безпеки та перевитрачаються сировина і матеріали відрядну систему оплати праці застосовувати не доцільно.

Форми оплати праці будуть ефрективними лише в тому разі, якщо вони відповідають організаційнотехнічним умовам виробництва. Отже, вибираючи форму оплати праці для певної категорії робітників, необхідно враховувати конкретні умови їхньої праці, спещифіку виробництва тощо. Основними (загальними) умовами застосування тієї чи іншої форми заробітної плати $е$ рівень технічною оснащення виробництва, характер технологічного процесу та організації виробництва і праці, ступінь використання виробничих потужностей і устаткування, стан нормування праці тощо [21, с. 51].

Заробітна плата відіграе важливу роль в житті кожного працюючого та важливою мотиваційною складовою продуктивності зайнятості. I тому підприемства повинні забезпечити всіма необхідними умовами працюючих організувавши систему оплати праці. Адже правильна організація заробітної плати на підприемстві мае бути спрямована на підвищення продуктивності, ефрективності та мотивації праці. I саме тому підприемства і організації мають використовувати всі методи і підходи для морального і матеріального стимулювання працівників, а саме достойна заробітна плата, правильне застосування форм оплати праці, забезпечення усіх належних умов праці.

Висновки. Отже, заробітна плата - це плата, яку виплачуе роботодавець працівнику, як винагороду за виконану роботу в грошовому виразі, що стимулюе його до досягнення високих кінцевих результатів праці, з одного боку і елемент витрат виробництва з іншого.

Проаналізувавши поняття оплати праці ми маємо можливість визначити це поняття, таким чином - заробітна плата - це ціна, якою оцінюється праця робітника, яка повинна бути виражена тільки в грошовому еквіваленті, і стимулювати до високих результатів, а також виступае одним з елементів витрат виробництва.

Організація системи заробітної плати на сільськогосподарському підприемстві має бути ретельно продумана, щодо критеріїв продуктивності, що підвищують зацікавленість працівників як в індивідуальних показниках, так і в кінцевих результатах роботи господарюючого суб’екта.

Організація та будова систем оплати праці є досить складним завданням для будь-якого виробництва, оскільки складно врахувати всі індивідуальні нюанси в організації та структурі для кожного конкретного підприємства.

Дослідивши функції оплати праці пропонуемо виділяти основні такі як: відтворювальна, стимулююча, регулююча та соціальна, кожна з яких має свій власний механізм реалізації, адже інші функції лише дублюють основні, незважаючи на варіації назв та підходів.

Разом 3 тим, подальше вироблення стандартів і розробка процедур на основі найкращої практики впровадження систем організування пращі на виробництві допоможе забезпечити збалансування та відповідність між індивідуальними особливостями і універсальними методиками в організуванні виробничих процесів [20, с. 130].

\section{Список літератури:}

1. Глухова С.В. Підходи до сутності заробітної плати. Молодий вчений. 2016. № 12.1 (40). С. 698-701.

2. Сьомченко В.В., Засипко К.О. Заробітна плата як соціально-економічна категорія. Вісник Запорізького національного університету. 2016. № 1(29). С. 121-127.

3. Маркевич А.Є. Економічний зміст та підходи до поняття «заробітна плата» Ефбективна економіка. 2015. № 2. URL: http://www.economy.nayka.com.ua

4. Про оплату праці : Закон України від 24.03.1995 № 108/95-ВР : станом на 01.01.2009. Офіційний сайт Верховної Ради України. URL: zakonl.rada.gov.ua

5. Круш П.В., Тульчинська С.О. Макроекономіка : навчальний посібник : 2-ге вид., перероб. та доопрацювання. Київ : Центр учбової літератури, 2008. 328 с.

6. Лукашевич В.М. Економіка праці та соціально-трудові відносини : навчальний посібник. Львів : «Новий світ», 2004. $248 \mathrm{c}$.

7. Болотіна Н.Б., Чанишева Г.І. Трудове право України : підручник. Київ : «Знання», 2000. 564 с.

8. Брезицька К.Ф. Аналіз сучасних систем оплати праці в зарубіжних країнах. Управління розвитком. 2011. № $8(105)$. C. $30-31$.

9. Мочерний С.В. Політична економія : навчальний посібник. Київ : «Знання-Прес», 2006. 687 с.

10. Гадзевич О.І. Оплата праці в умовах ринку: теорія, практика : навчальний посібник. Київ : КОНДОР, 2008. 400 с.

11. Калина А.В. Економіка праці : навчальний посібник. Київ : МАУП, 2009. 272 с.

12. Завіновська Г.Т. Економіка праці : навчальний посібник. Київ : КНЕУ, 2008. 300 с. 
13. Петрова І.Л. Український ринок праці: особливості розвитку та ефективність фрункціонування : монографрія. Київ : «Фенікс», 2010. 332 с.

14. Колот А.М., Грішнова О.А., Герасименко О.О. та ін. Економіка праці та соціально-трудові відносини : підручник. Київ : КНЕУ, 2009. 711 с.

15. Шевченко Л.С. Основи економічної теорії : підручник. Харків : ПРАВО, 2008. 448 с.

16. Буряк П.Ю. Економіка праці й соціально-трудові відносини: підручник. Київ : Центр навчальної літератури, 2010. $440 \mathrm{c}$.

17. Грішнова О.А. Людський розвиток : навчальний посібник. Київ : КНЕУ, 2009. 308 с.

18. Практические рекомендации по мотивации, стимулированию и оплате труда / В.Н. Слиньков; за ред. В.Н. Слиньков. Київ : Дакор КНТ, 2010. 336 с.

19. Швиданенко Г.О., Васильков В.Г., Гончарова Н.П. та ін. Економіка підприемства : підручник. Київ : КНЕУ, 2009. $598 \mathrm{c}$.

20. Воронін О. Визначення показників економічної ефрективності виробництва на основі модифікації ресурсного потенціалу. Еконоліка України. 2007. № 10. С. 29-37.

21. Пищуліна О.М. Нова ідеологія реформування заробітної плати: потреба та перспективи. Cmpaтегічні пріоритети. 2009. № 4. С. 140-147.

22. Дробишева O.О., Домаш Д.В. Економічна сутність, форми та системи оплати праці. URL: http://www.zgia.zp.ua/ gazeta/evzdia_8_048.pdf

23. Онищенко В. Форми оплати праці. Головбух. 2018. № 6. URL: https://www.golovbukh.ua/article/7319-formioplati-prats

\section{References:}

1. Hlukhova, S.V., \& Zotova A.A. (2016). Pidkhody do sutnosti zarobitnoi platy. Molodyi vchenyi, 12.1 (40), 698-701. (in Ukrainian)

2. Somchenko, V.V. \& Zasypko K.O., (2016). Zarobitna plata yak sotsialno-ekonomichna katehoriia. Visnyk Zaporizkoho natsionalnoho universytetu, 1(29), 121-127. (in Ukrainian)

3. Markevych, A.Ie. (2015). Ekonomichnyi zmist ta pidkhody do poniattia "zarobitna plata». Efektyvna ekonomika, no. 2. URL: http://www.economy.nayka.com.ua (in Ukrainian)

4. Pro oplatu pratsi: Zakon Ukrainy vid 24.03.1995 № 108/95-VR: stanom na 01.01.2009.Ofitsiinyi sait Verkhovnoi Rady Ukrainy. URL: zakonl.rada.gov.ua

5. Krush, P.V., Tulchynska, S.O. (2008). Makroekonomika: navch. posib. [2-he vyd., pererob. ta dop.]. Kyiv: Tsentr uchbovoi literatury. (in Ukrainian)

6. Lukashevych, V.M. (2004). Ekonomika pratsi ta sotsialno-trudovi vidnosyny: navch. posib. Lviv: Novyi svit, 248. (in Ukrainian)

7. Bolotina, N.B., Chanysheva, H.I. (2000) Trudove pravo Ukrainy: pidruch. Kyiv: vydavnytstvo Znannia, KOO. (in Ukrainian)

8. Brezytska, K.F. (2011). Analiz suchasnykh system oplaty pratsi v zarubizhnykh krainakh. Upravlinnia rozvytkom, 8(105), 30-31. (in Ukrainian)

9. Mochernyi, S.V. (2006). Politychna ekonomiia: navch. posib. Kyiv: Znannia-Pres. (in Ukrainian)

10. Hadzevych, O.I. (2008). Oplata pratsi v umovakh rynku: teoriia, praktyka. Kyiv: vydavnytstvo KONDOR. (in Ukrainian)

11. Kalyna, A.V. (2008). Ekonomika pratsi: navchalnyi posibnyk. Kyiv: vydavnytstvo MAUP. (in Ukrainian)

12. Zavinovska H.T. (2008). Ekonomika pratsi: navchalnyi posibnyk. Kyiv: vydavnytstvo KNEU. (in Ukrainian)

13. Petrovoi, I.L. (2010). Ukrainskyi rynok pratsi: osoblyvosti rozvytku ta efektyvnist funktsionuvannia: monohrafiia / Za red. d-ra ekon. nauk, prof. I.L. Petrovoi. Kyiv: vydavnytstvo Feniks. (in Ukrainian)

14. Kolot, O.A., Hrishnova, O.O. \& Herasymenko, O.O. (2009). Ekonomika pratsi ta sotsialno-trudovi vidnosyny: pidruchnyk / za nauk. red. d-ra ekon. nauk, prof. A.M. Kolota (Ed.). Kyiv: vydavnytstvo KNEU. (in Ukrainian)

15. Shevchenko, L.S. (2008). Osnovy ekonomichnoi teorii / Za zah. red. d-ra ekon. nauk, prof. L.S. Shevchenko. Kharkiv: Pravo. (in Ukrainian)

16. Buriak, P.Iu. (2010). Ekonomika pratsi y sotsialno-trudovi vidnosyny: pidruchnyk. Kyiv: Tsentr navchalnoi literatury. (in Ukrainian)

17. Hrishnova, O.A. (2009). Liudskyi rozvytok. Kyiv: KNEU. (in Ukrainian)

18. Slinkov, V.N. (2010). Motyvatsyia, stymulyrovanye y oplata truda: Praktycheskye rekomendatsyy. Kyiv: vydavnytstvo Dakor KNT. (in Ukrainian)

19. Shvydanenko, H.O., Vasylkov, V.H., \& Honcharova, N.P. (2009). Ekonomika pidpryiemstva: pidruchnyk. H.O. Shvydanenko (Ed.). Kyiv: vydavnytstvo KNEU. (in Ukrainian)

20. Voronin, O. (2007). Vyznachennia pokaznykiv ekonomichnoi efektyvnosti vyrobnytstva na osnovi modyfikatsii resursnoho potentsialu. Ekonomika Ukrainy, 10, 29-37. (in Ukrainian)

21. Pyshchulina, O.M. (2009). Nova ideolohiia reformuvannia zarobitnoi platy: potreba ta pespektyvy. Stratehichni priorytety, 4, 140-147. (in Ukrainian) 